\title{
Attractivity of omnivore, carnivore and herbivore mammalian dung to Scarabaeinae (Coleoptera, Scarabaeidae) in a tropical Atlantic rainforest remnant
}

\author{
Bruno K. C. Filgueiras ${ }^{1}$, Carolina N. Liberal², Cristina D. M. Aguiar³ ${ }^{3}$ Malva I. Medina Hernández ${ }^{4}$ \\ \& Luciana Iannuzzi ${ }^{5}$
}

\begin{abstract}
1Departamento de Zoologia, Universidade Federal de Pernambuco, Cidade Universitária, 50670-901 Recife-PE, Brazil. bkcfilgueiras@ gmail.com ${ }^{2}$ carolinaliberal@gmail.com

${ }^{3}$ crixmaia@oi.com.br

${ }^{4}$ Programa Regional de Pós-Graduação em Desenvolvimento e Meio Ambiente, Universidade Federal da Paraíba, 58059-900 João Pessoa-PB, Brazil. malvamh@yahoo.com

5iannuzzi@ufpe.br
\end{abstract}

\begin{abstract}
Attractivity of omnivore, carnivore and herbivore mammalian dung to Scarabaeinae (Coleoptera, Scarabaeidae) in a tropical Atlantic rainforest remnant. In this study, performed in a remnant of Brazilian Atlantic Forest, three types of dung from animals with distinct alimentary habits were utilized, in order to verify possible differences of attractivity of these dungs to the Scarabaeinae and the influence of seasonality in the attractivity. Three habitats were sampled: edge, clearing and forest core, each with 40 pitfall traps. A total of 2,137 beetles were collected from August 2005 to July 2006. Canthidium sp. 1 (43\%) and Dichotomius sericeus (41\%) were the most abundant species. From the total number of beetles collected, $80.5 \%$ were attracted to human dung, $11 \%$ to jaguar dung, $7.8 \%$ to waterbuck dung and $0.7 \%$ to the control. The species Canthidium sp.1, Canthidium sp. 2, Ateuchus sp., Canthon nigripenne, Canthonella sp. and D. sericeus came to all three bait types. Eight species were found in the baits with human dung, where Canthidium sp.1 (49\%) and D. sericeus (39\%) were the most common. A significant difference in attractiveness of the different baits was observed; the highest abundance found in traps baited with human dung $(\mathrm{F}=36.59 ; \mathrm{g} .1 \mathrm{l}=3 ; \mathrm{p}$ $<0.0001)$. A significant difference in richness was observed between rainy and dry seasons $(\mathrm{F}=12.29 ; \mathrm{g} .1 \mathrm{l}=1 ; \mathrm{p}<0.001)$, the highest richness found in the dry season.
\end{abstract}

KEYWORDS. Atlantic forest; bait; dung beetles; seasonality.

RESUMO. Atratividade de Scarabaeinae (Coleoptera: Scarabaeidae) por fezes de mamíferos onívoros, carnívoros e herbívoros em um remanescente de Floresta Tropical Atlântica. Nesse estudo, realizado em um remanescente de Floresta Atlântica Brasileira, três tipos de fezes de animais com distintos hábitos alimentares foram utilizados para verificar possíveis diferenças de atratividade dessas fezes por Scarabaeinae e a influência da sazonalidade nessa atratividade. Três habitats foram amostrados: borda, clareira e núcleo da floresta, cada um com 40 armadilhas de queda ("pitfall"). Um total de 2137 besouros foi coletado de agosto de 2005 a julho de 2006. Canthidium sp. 1 (43\%) e Dichotomius sericeus (41\%) foram as espécies mais abundantes. Do número total de besouros coletados, $80,5 \%$ foram atraídos para fezes humanas, $11 \%$ para fezes de jaguar, 7,8\% para fezes de cobo e 0,7\% para o controle. As espécies Canthidium sp.1, Canthidium sp. 2, Ateuchus sp., Canthon nigripenne, Canthonella sp. e D. sericeus foram aos três tipos de isca. Oito espécies foram encontradas nas iscas com fezes humanas, onde Canthidium sp.1 (49\%) e D. sericeus (39\%) foram as mais abundantes. Diferença significativa de atratividade por diferentes iscas foi observada; a maior abundância foi evidenciada em armadilhas iscadas com fezes humanas $(\mathrm{F}=36.59 ; \mathrm{g} .1 .=3 ; \mathrm{p}<0.0001)$. Diferença significativa foi observada na riqueza entre as estações chuvosa e seca $(\mathrm{F}=12.29$; g.1. $=1 ; \mathrm{p}<0.001)$ sendo a maior riqueza verificada na estação seca.

PALAVRAS-CHAVE. Besouros coprófagos; Floresta Atlântica; isca; sazonalidade.

The beetles of the subfamily Scarabaeinae (Coleoptera, Scarabaeidae) are well represented insects in tropical regions, and recently have been used in monitoring biodiversity studies (Halffter \& Favila 1993; Davis et al. 2001; Rensburg \& Botes 2002). The communities of these beetles are very sensitive to habitat alteration and have distinct organization patterns when studied in tropical forest fragments or in areas which have been deteriorated by human action (Howden \& Nealis 1975; Janzen 1983; Klein 1989; Halffter et al. 1992; Didham et al. 1998; Lobo \& Martín-Piera 1999; Gardner et al. 2008).

Besides function as an information source for inventories, monitoring and about landscape alterations, the Scarabaeinae have important ecological roles. These roles include efficient and rapid nutrient cycling, with organic matter processing, and the improvement of its availability to the environment (Halffter \& Matthews 1966; Bornemissa \& Williams 1970; Nealis 1977); secondary seed dispersal of many Neotropical tree species, playing an important role on the natural process of forest regeneration (Estrada \& Coates-Estrada 1991), as well as controlling eggs and larvae of parasites which are present on fresh mammal excrement (Bergstrom et al. 1976; Flechtmann et al. 1995).

Dung, mainly mammalian dung, is one of the resources used by the Scarabaeinae as a food for larvae and adults and 
as a substrate for oviposition. Fungi, decomposing vegetables, and carcasses are also used by some species as food resource (Halffter \& Matthews 1966). Such feeding diversification is believed to have occurred in Neotropical Forest due to the extinction of large mammals during the Pleistocene (Halffter 1991), leading the beetles to use different sources of food other than dung.

The presence of excrement associated with other factor such as climate, mainly temperature and precipitation, in addition to altitude, may affect the spatial and temporal distribution of Scarabaeinae (Fincher 1973; Halffter \& Edmonds 1982; Escobar et al. 2006). Dung beetle communities are known to respond to changes in rainfall (Hanski \& Cambefort 1991). In general, at the tropical region, their communities show higher abundance and richness during the rainy season (Cambefort 1991; Andresen 2005). Thus, the present study compares the attraction of three different types of excrement: jaguar (carnivorous), waterbuck (herbivorous) and human dung (omnivorous) to Scarabaeinae verifying if there are oscillations on the attractiveness of the dung to Scarabaeinae, associated with seasonality in Atlantic Forest remnant in the northeast of Brazil.

\section{MATERIAL AND METHODS}

Study area

The study was conducted at the Parque Estadual de Dois Irmãos, a Brazilian remnant of Atlantic rain forest in the state of Pernambuco, Recife municipality $\left(7^{\circ} 55^{\prime}-8^{\circ} 09^{\prime} \mathrm{S}, 34^{\circ} 52^{\prime}-\right.$ $\left.35^{\circ} 00^{\prime} \mathrm{W}\right)$. This reserve is a forest fragment with 387.4 ha, isolated in a predominantly urban landscape (Tabarelli 1998).

According with Köppen's climate classification, Recife's climate is As', warm and humid coastal tropical, with an annual average temperature of $23^{\circ} \mathrm{C}$. The rain regimen occurs during autumn-winter (March-August), with higher average precipitation during June and July. The annual pluviometric average is $2,460 \mathrm{~mm}$, having a hydric deficiency period from October to January, thus characterizing the dry season (Coutinho et al. 1998).

\section{Insect Collection}

Sampling was performed monthly from August 2005 to July 2006, using pitfall traps, arranged in three distinct areas of the forest: edge (until $100 \mathrm{~m}$ of the edge), interior (from $200 \mathrm{~m}$ of the edge) and clearings. Transects of $150 \mathrm{~m}$ were established in the edge and interior of the forest, however, due to the spatial distribution of the clearings it wasn't possible to establish transects in them. Each area had 10 sets of traps spaced $15 \mathrm{~m}$ apart (except in the clearings, where the distance varied), each set comprised four traps set $2 \mathrm{~m}$ apart from each other, disposed in a square shape. The trap consisted of a plastic recipient with a $9.5 \mathrm{~cm}$ diameter. In each set of traps three types of bait coming from mammals with different eating habits were distributed: omnivorous habit (human excrement); carnivorous habit \{jaguar excrement, Panthera onca (Linnaeus, 1758) \} and herbivorous habit (waterbuck excrement, Kobus ellipsiprymnus Ogilby, 1833). The last two types of excrement were collected in the zoo of Parque Estadual de Dois Irmãos. One of the four traps in each set was not baited serving as a control for the study. Traps were buried on the ground and were protected from rain by a suspended polystyrene disc. The traps stayed in the field for $48 \mathrm{~h}$ before being collected. The material is deposited at the "Coleção Entomológica da Universidade Federal de Pernambuco".

\section{Data analysis}

The attractiveness of each type of bait to Scarabaeinae was verified through the Levins's standardized index $\left(B_{A}\right)$, measuring the niche width of species with $N>50$. The calculation of Levins index was done with the software Ecological Methodology (Kenny \& Krebs 2000). The species which had Levins's $\left(B_{A}\right)$ values equal or lower than 0.5 were considered as specialists and the species with values upper than 0.5 were considered as generalists (Krebs 1999).

Multivariate analyses were performed aiming to discriminate possible spatial-temporal differences in the Scarabaeinae communities in terms of consistent abundance changes. For that purpose the types of bait were compared, using non-metric multidimensional scaling (NMDS) from Primer program (Clarke and Gorley 2001). This analysis was implemented over a similarity matrix (Bray-Curtis Similarity) constructed over an abundance data by species matrix, for each type of bait used throughout the period of study. The bi dimensional configuration of the similarities trustworthiness was evaluated by the measure of STRESS, which varies on an increasing scale from 0 to 1 . The relationship of bait type to the similarity between traps during 12 months was analyzed using ANOSIM tests (Clarke and Gorley 2001).

Pearson $\left(\mathrm{r}^{2}\right)$ coefficient of correlation was used to verify the relation of Scarabaeinae abundance and richness with pluviometry and temperature. Richness data were transformed by adding their square roots to 0.5 of their initial value.

To evaluate the distinction of Scarabaeinae mean abundances and richness by trap during the dry season and the rainy season, an ANOVA Two Way test was performed using the software Statistica 6.0 (Statsoft, Inc. 2004). In order to homogenize the variances and normalize the residues, both the abundance and richness were transformed by adding their square roots to 0.5 of their initial value.

\section{Meteorological data}

Data referring to temperature and precipitation from August 2005 to July 2006 were provided by INMET (National Meteorology Institute). The base for data collection of INMET covers a radius of $10 \mathrm{~km}$ from the metropolitan area of Recife. The Parque Estadual de Dois Irmãos is inserted in that radius specified.

\section{RESULTS}

Richness and abundance of species

A total of 2,137 beetles from 11 species were collected 


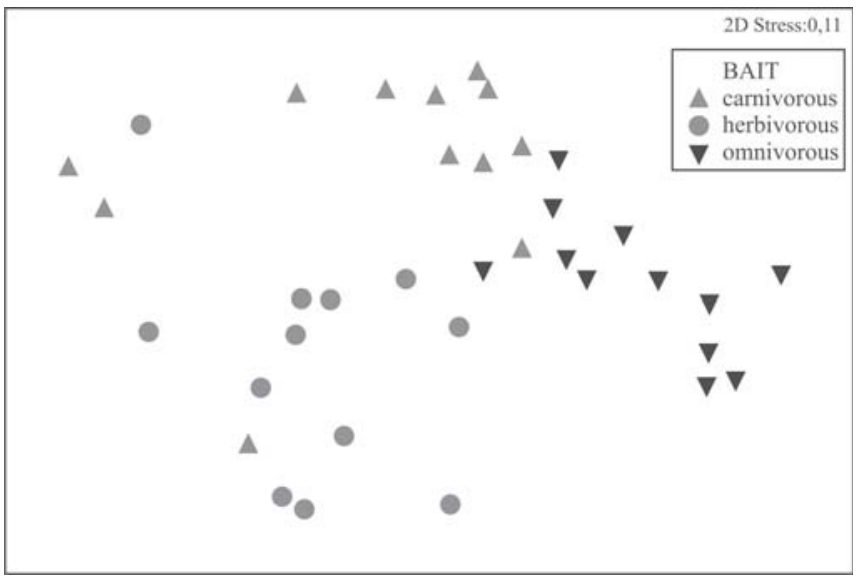

Fig. 1. NMDS showing the grouping of Scarabaeinae according to each type of bait (omnivorous, herbivorous and carnivorous) from August 2005 to July 2006, using Bray-Curtis similarity.

during the study. Two species were particularly abundant: Canthidium sp.1 (43\% of the total) and Dichotomius sericeus (Harold, 1867) (41\%). ANOSIM analysis revealed significant distinctions between bait type and the abundance of Scarabaeinae by trap during 12 months $(R=0.545, P=0.001)$.

\section{Bait attractiveness}

From the total of the collected beetles, $80.5 \%$ were attracted to human dung, $11 \%$ were attracted to jaguar dung, $7.8 \%$ were attracted to waterbuck dung and $0.7 \%$ was found in the control traps. In traps baited with human dung individuals from eight species were collected, with Canthidium sp. 1 (49\%) and D. sericeus (39\%) being the most common species. In traps baited with jaguar dung, nine species were found, D. sericeus $(69.5 \%)$ and Canthon nigripenne Lansberge, 1874 (12.5\%) were the most representative. In traps baited with waterbuck dung seven species were notified, wich Ateuchus sp. (45.5\%), Canthidium sp.1 (23\%) and D. sericeus (22\%) were the dominant species. The species Canthidium sp.1, Canthidium sp.2, Ateuchus sp., Canthon nigripenne, Canthonella sp. and $D$. sericeus were attracted to the three types of baits (Table I). Canthidium sp.1 $\left(B_{A}=0.06\right)$, Canthidium sp.2 $\left(B_{A}=0.11\right)$ and D. sericeus $\left(B_{A}=0.30\right)$ were considered specialists for human dung. Whereas, Ateuchus sp. $\left(B_{A}=0.70\right)$ was a generalist species, with no preference for a determined type of bait. The two-dimensional configuration formed by the NMDS, with a STRESS of 0.11, showed distinct clusters for each type of bait during the period studied (Fig. 1).

Seasonal influence on the attractiveness of baits

The Scarabaeinae appeared in every month of the collection, with the period among August (14\% of total individuals), September (12\% of total individuals), October (17\% of total individuals), November (14\% of total individuals), and December (13\% of total individuals) having the highest proportions of individuals in respect to the total of individuals collected. In these months, Scarabaeinae were better represented when human dung was used as bait. The beetles captured using waterbuck excrement as bait occurred more frequently during September (1.5\%) and August (1.0\%), while the species collected using jaguar excrement as bait had higher abundance in January (2.5\%) and June (1.5\%) (Fig.2). January had the lowest precipitation $(12.3 \mathrm{~mm})$. Possibly, all these results were due to dominants species.

The highest peaks of precipitation and temperature, during the period of the study, were, respectively, $432 \mathrm{~mm}$ (June) and $27.7^{\circ} \mathrm{C}$ (February) (Fig.3). Temperature $\left(r^{2}=0.1, P=0.32\right)$ as much as precipitation $\left(r^{2}=0.08, P=0.40\right)$ were not effectively correlated with the abundance of the Scarabaeinae.

When the abundance of Scarabaeinae within the different treatments (baits and control) was tested between the two seasons, there was no interaction of the factors among the parameters $(\mathrm{F}=2.52$; d.f. $=3 ; 472 ; \mathrm{p}=0.06)$. There was significant difference between the seasons $(F=6.40$; d.f. $=1$; $472 ; \mathrm{p}=0.01)$. It is important to highlight that only the Scarabaeinae attracted to human dung differed in abundance between seasons (Fig. 4a). A significant difference of attractiveness to different baits was observed too with the higher abundance found in traps baited with human dung $(\mathrm{F}=$ 180.81 ; d.f. $=3 ; 472 ; \mathrm{p}<0.0001$ ). This result was influenced by the abundance of the Scarabaeinae attracted to human dung (Fig. 4a).

Temperature $\left(r^{2}=0.03, P=0.60\right)$ as much as precipitation $\left(r^{2}=0.08, P=0.36\right)$ were not correlated with Scarabaeinae richness. When the richness of Scarabaeinae within treatments (baits and control) was tested between the two seasons, there was interaction of the factors among the parameters $(\mathrm{F}=2.63$; d.f. $=3 ; p=0.05)$. A significant difference was observed between rainy and dry seasons $(\mathrm{F}=4.26$; d.f. $=1 ; \mathrm{p}=0.04)$, with the higher richness found in the dry season. This result was, nevertheless, influenced by the richness of the Scarabaeinae attracted to human dung (Fig. 4b). There was also a significant difference among baits $(F=147.09$; d.f. $=3 ; \mathrm{p}$

Table I. Total number of Scarabaeinae attracted to excrements of omnivorous (human), carnivorous (jaguar) and herbivorous (waterbuck) mammals plus the control traps, from August 2005 to July 2006, in Parque Estadual de Dois Irmãos, Pernambuco, Brazil.

\begin{tabular}{lccccc}
\hline Species & $\begin{array}{c}\text { Omni- } \\
\text { vorous }\end{array}$ & $\begin{array}{c}\text { Carni- } \\
\text { vorous }\end{array}$ & $\begin{array}{c}\text { Herbi- } \\
\text { vorous }\end{array}$ & Control & Total \\
\hline Ateuchus sp. & 72 & 17 & 76 & 3 & 168 \\
Canthidium sp. 1 & 856 & 15 & 38 & 4 & 913 \\
Canthidium sp. 2 & 99 & 1 & 10 & 2 & 112 \\
Canthidium sp. 3 & 0 & 1 & 0 & 0 & 1 \\
Canthon nigripenne & 12 & 30 & 3 & 0 & 45 \\
Canthonella sp. & 5 & 5 & 2 & 0 & 12 \\
Coprophanaeus jasius & 0 & 0 & 1 & 0 & 1 \\
Deltochilum morbillosum & 0 & 2 & 0 & 0 & 2 \\
Dichotomius bicuspis & 1 & 2 & 0 & 0 & 3 \\
Dichotomius sericeus & 671 & 166 & 37 & 5 & 879 \\
Onthophagus sp. & 1 & 0 & 0 & 0 & 1 \\
Total number of & & & & & \\
individuals & 1717 & 239 & 167 & 14 & 2137 \\
Total number of species & 8 & 9 & 7 & 4 & 11 \\
\hline
\end{tabular}




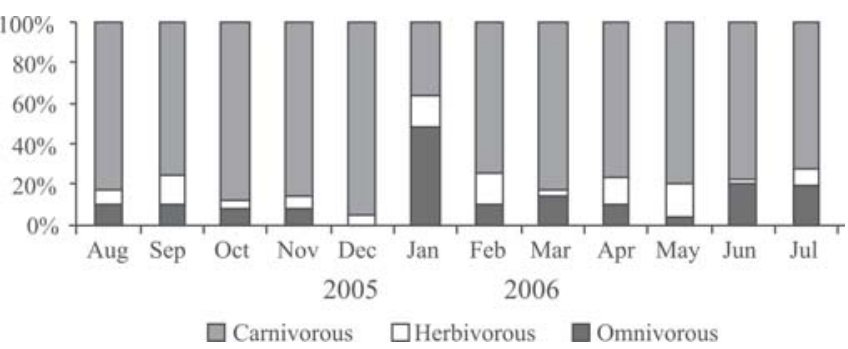

Fig. 2. Proportion of individuals of Scarabaeinae distributed monthly from August 2005 to July 2006 for each type of bait that was used: human (omnivorous), jaguar (carnivorous) and waterbuck (herbivorous) excrement.

$<0.0001)$. The species Canthonella sp., Onthophagus sp., Deltochilum morbillosum Burmeister, 1848, Coprophanaeus jasius (Olivier, 1789) and Canthidium sp. 3 were found only during this dry season. The Dichotomius bicuspis (Germar, 1824) species had only three specimens recorded and were restricted to the rainy season (Table II).

The dry season had higher Scarabaeinae richness with the species Canthonella sp., Onthophagus sp., Deltochilum morbillosum, Coprophanaeus jasius and Canthidium sp. 3 found only during this season. The D. bicuspis species had only three specimens reported and were restricted to the rainy season.

\section{DISCUSSION}

In this study there was a distinction of attractiveness of different types of dung to Scarabaeinae, which was higher in human dung, and that there was a seasonal component to the number of beetles captured.

The proportion of individuals collected at each type of bait differed in its distribution pattern during the months sampled, corroborating with the results obtained by Estrada et al. (1993), which showed discrepancies in Scarabaeinae distribution during dry and rainy seasons. Nevertheless, the higher abundance reported during the dry season, does not support Halffter \& Mathews (1966), Janzen (1983) and Stumpf's (1986) proposals, according to which, in tropical humid forests abundance rise after the beginning of the rainy season. From August to December, the low-precipitation period, omnivorous dung bait (human dung) and herbivorous dung bait (waterbuck dung) presented a pattern with the highest percentage values in terms of individuals. The carnivore dung bait (jaguar dung) did not correspond to this pattern, as it had higher percentages in number of individuals on the months of January and July. Such differences, in terms of seasonal distribution pattern are in accord with Halffter \& Edmonds' (1982) proposal, which affirms, generally, that temperature and precipitation are the climatic factors that most affect spatial and temporal distribution of Scarabaeinae.

Many small and medium-sized forest fragments ( $<500 \mathrm{ha})$ are not capable of sustaining large herbivorous vertebrate populations, top predators, and frugivorous primates and

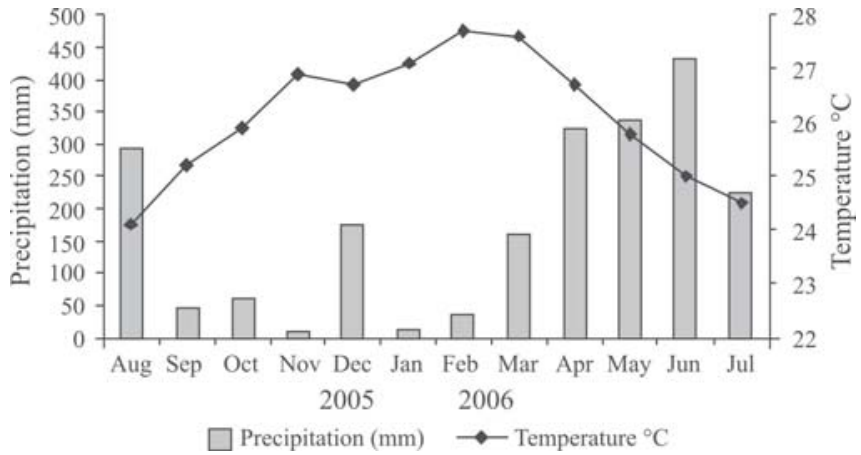

Fig. 3. Mean monthly rainfall and temperatures from August 2005 to July 2006 in Parque Estadual de Dois Irmãos, Pernambuco, Brazil.

birds (Lovejoy et al. 1984, 1986; Arango-Vélez \& Kattan 1997). Possibly, the limited amount of food in terms of excrement, in Parque Estadual de Dois Irmãos, may explain the predominance of just a few species, in this case Canthidium sp. 1 and $D$. sericeus, over the others species. Together these two species represented $84 \%$ of the total number of the beetles collected. When little food is available, intense competition results in strict specialization on a particular resource (Cambefort \& Hanski 1991; Hanski 1989, 1991). So, the most abundant species were not sensitive to a specialization of the diet, because the majority of the beetles in the genus Canthidium Erichson (1847) and Dichotomius Hope, 1838 are often associated with habitat modification, where there are abundant resources for these species (Andresen 2005; Silva et al. 2007).

Concerning the feeding habits, three species were considered specialists and one species, generalist (through the Levins's standardized index - BA). This result differs from the findings of Silva et al. (2007), in a fragment of a Tropical altitudinal Rainforest, in the Pernambuco, Brazil ("Brejos de Altitude"), in which the majority of species was generalist. It also goes against the hypothesis of Halffter \& Matthews (1966), which assumes that diet generalization is a characteristic of all Neotropical Scarabaeinae communities. Probably this was the

Table II. Total number of Scarabaeinae attracted to excrements of omnivorous, carnivorous and herbivorous mammals plus the control traps, through rainy and dry season, in Parque Estadual de Dois Irmãos, Pernambuco, Brazil.

\begin{tabular}{lcc}
\hline Species & Rainy season & Dry season \\
\hline Ateuchus sp. & 51 & 117 \\
Canthidium sp. 1 & 298 & 615 \\
Canthidium sp. 2 & 31 & 81 \\
Canthidium sp. 3 & 0 & 1 \\
Canthon nigripenne & 9 & 36 \\
Canthonella sp. & 0 & 12 \\
Coprophanaeus jasius & 0 & 1 \\
Deltochilum morbillosum & 0 & 2 \\
Dichotomius bicuspis & 3 & 0 \\
Dichotomius sericeus & 315 & 564 \\
Onthophagus sp. & 0 & 1 \\
Total & 707 & 1430 \\
\hline
\end{tabular}



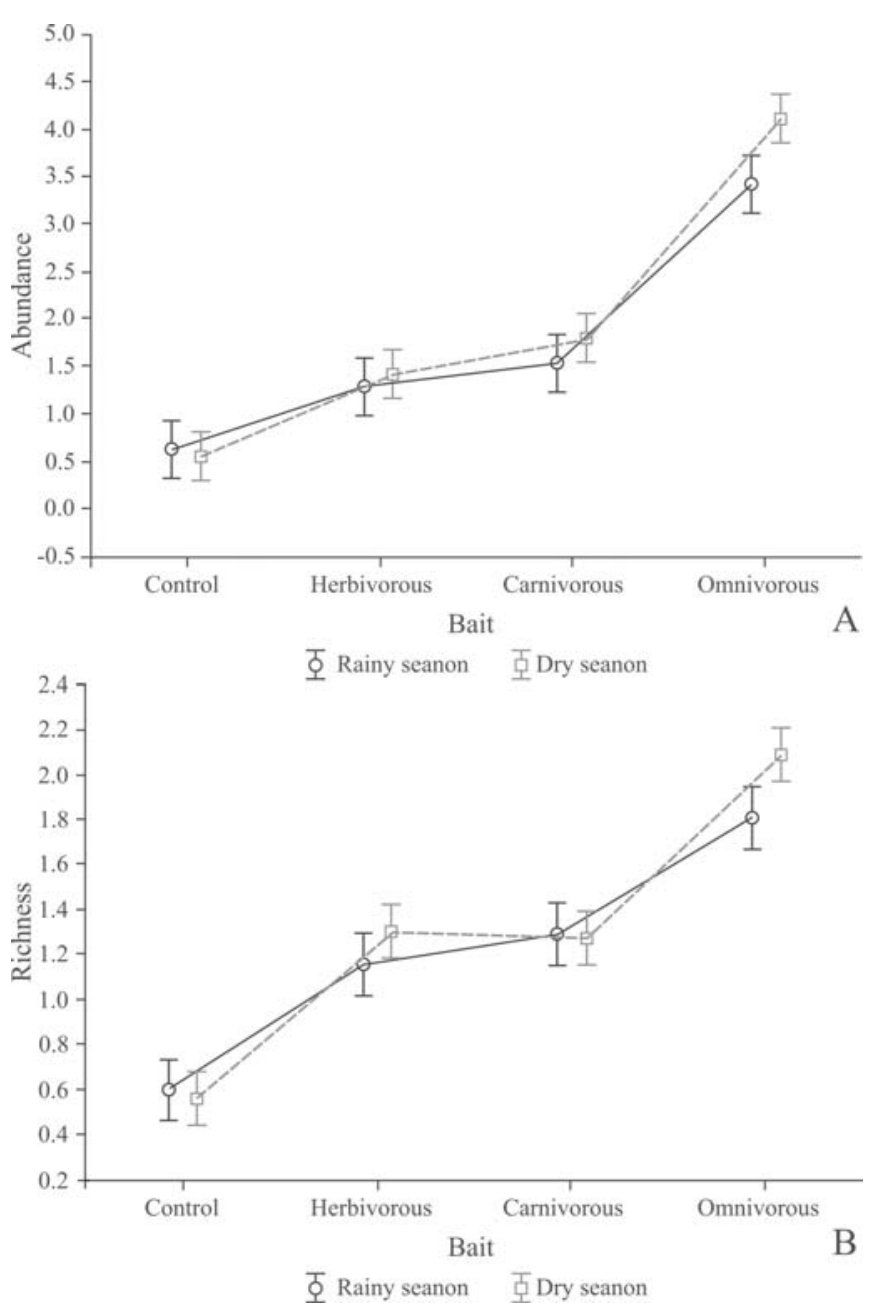

Fig. 4. ANOVA Two-Way analysis characterizing the difference between Scarabaeinae abundances and richness throughout the dry season and the rainy season, for each type of bait that was used: human (omnivorous), jaguar (carnivorous) and waterbuck (herbivorous) excrement in Parque Estadual de Dois Irmãos, Pernambuco, Brazil. $($ Mean $\pm \mathrm{SD})$.

cause for such results. Besides, not all species sampled by Silva et al. (2007) were found in the Parque Estadual de Dois Irmãos. Only Canthidium species were considered by both as specialists.

The species Canthidium sp.3 and Deltochilum morbillosum were only found at the carnivorous dung bait, while Coprophanaeus jasius occurred in the herbivorous dung bait and Onthophagus sp. in the omnivorous dung bait. These species had lower representation in terms of abundance. In this case, the stenophagy hypothesis is discarded. The fact that such species present a lower abundance can be associated with their higher vulnerability due to diet specialization (Halffter $\&$ Matthews 1966). One species from the genus Coprophanaeus d'Olsoufieff, 1924 was reported at the herbivorous dung bait, a genus predominantly necrophagous (Endres et al. 2005). The absence or presence of an abundant excrement resource is one of the factors that may determine Scarabaeinae occurrence and distribution in certain biomes.
Considering Scarabaeinae as a whole, the main food resource used by the majority of the species, larvae and adults, is large mammals' excrement. In Parque Estadual de Dois Irmãos, the largest number of beetles (85\%) was captured by traps containing human excrement, showing the fact that this type of bait is especially attractive in forests. However, even in pasture, human dung is rapidly attacked by a variety of Scarabaeinae species (Halffter \& Matthews 1966).

The results obtained in Parque Estadual de Dois Irmãos are in accordance with Fincher et al. (1970), who verified attractiveness of various types of excrement to Scarabaeinae, in the state of Georgia, USA, where the dung of omnivorous animals had the largest number of coprophagous beetles captured. This same premise was attested by Estrada et al. (1993) who compared attractiveness of the dung of herbivorous animal \{Alouatta palliata (Gray, 1849)\} excrement and omnivorous animal \{Nasua narica (Linnaeus, 1766)\} excrement to Scarabaeinae in a tropical forest of Mexico, and found that the excrement from the omnivorous animal had a higher abundance of beetles than other types. As the lowest values of abundance were found in the control traps, that is, with no bait, we conclude that there is attractiveness of excrement from animals with distinct feeding habits to Scarabaeinae, with the excrements of omnivorous animals the ones which are most attractive.

Acknowledgements. The authors thank F.Z. Vaz-de-Mello for confirming and identifying beetle's species and INMET for Meteorological data. We wish to thank to employees from Parque Estadual de Dois Irmãos and Scott V. Heald for improving the English version of the manuscript.

\section{REFERENCES}

Andresen, E. 2005. Effects of season and vegetation type on community organization of dung beetles in a tropical dry forest. Biotropica 37: 291-300.

Arango-Vélez, N. G. H. \& G. H. Kattan.1997. Effects of forest fragmentation experimental nest predation in Andean cloud forest. Biological Conservation 81: 137-143.

Bergstrom, B. C.; R. L. Maki \& B. A. Werner. 1976. Small dung beetles as biological control agents: laboratory studies of beetle action on trichostongylid and cattle dung. Proceedings of the Helminthology Society of Washington 43: 171-174.

Bornemissa, G. F. \& C. H. Williams. 1970. An effect of dung beetle activity and plant yield. Pedobiologia 10: 1-7.

Cambefort, Y. 1991. Dung beetles in tropical savannas, p. 156-178. In: I. Hanski \& Y. Cambefort (eds.). Dung Beetle Ecology Princeton, Princeton University Press, 481 p.

Cambefort. Y. \& I. Hanski. 1991. Dung Beetle Population Biology, p. 36-50. In: I. Hanski \& Y. Cambefort (eds.). Dung Beetle Ecology. Princeton, Princeton University Press, 481 p.

Clarke, K. R. \& R. N. Gorley. 2001. PRIMER v5: User Manual/ Tutorial. Plymouth, PRIMER-E, $91 \mathrm{p}$.

Coutinho, R. Q.; M. F. L. Filho; J. B. S. Neto \& E. P. Silva. 1998. Características Climáticas, Geológicas, Geomorfológicas e Geotécnicas do Parque Estadual de Dois Irmãos, p. 21-49. In: I. C. Machado; A. V. Lopes \& K. C. Porto (eds.). Parque Estadual de Dois Irmãos: estudos em um Remanescente de Mata Atlântica em Área Urbana (Recife - Pernambuco - Brasil). Recife, Editora Universitária da Universidade Federal do Pernambuco, $326 \mathrm{p}$. 
Davis, A. J.; J. D. Holloway; H. Huijbregts; J. Krikken; A. Kirk-Spriggs $\&$ S. L. Sutton. 2001. Dung beetles as indicators of change in the forests of northern Borneo. Journal of Applied Ecology 38: 593-596.

Didham, R. K.; P. M. Hammond; J. H. Lawton; P. Eggleton \& N. E. Stork. 1998. Beetles species responses to tropical forest fragmentation. Ecological Monographs 68: 295-323.

Endres, A. A.; M. I. M. Hernandez \& A. J. Creão-Duarte. 2005. Considerações sobre Coprophanaeus ensifer (Germar) (Coleoptera, Scarabaeidae) em um remanescente de Mata Atlântica no Estado da Paraíba, Brasil. Revista Brasileira de Entomologia 49: 427429.

Escobar, F.; J. M. Lobo \& G. Halffter. 2006. Assessing the origin of Neotropical mountain dung beetle assemblages (Scarabaeidae: Scarabaeinae): the comparative influence of vertical and horizontal colonization. Journal of Biogeography 33: 1793-1803.

Estrada, A. \& R. Coates-Estrada. 1991. Howling monkeys (Alouatta palliata) dung beetles (Scarabaeidae) and seed dispersal: ecological interactions in the tropical rain forest of Los Tuxtlas, Veracruz, Mexico. Journal of Tropical Ecology 7: 459-474.

Estrada, A.; G. Halffter; R. Coates-Estrada \& D. A. M. Junior. 1993. Dung beetles attracted to mammalian herbivore (Alouatta palliata) and omnivore (Nasua narica) dung in the tropical rain forest of Los Tuxtlas, México. Journal of Tropical Ecology 9: 45-54.

Fincher, G. T.; T. B. Stewart \& R. Davis. 1970. Attraction of coprophagous beetles to dung of various animals. The Journal of Parasitology 56: 378-383.

Fincher, G. T. 1973. Nidification and reproduction of Phaneus spp. in three textural classes of soil (Coleoptera: Scarabaeidae). Coleopterist Bulletin 27: 33-37.

Flechtmann, C. A. H.; S. R. Rodrigues \& M. C. Z. Seno. 1995. Controle biológico da mosca-dos-chifres (Haematobia irritans irritans) em Selvíria Mato Grosso do Sul. 3. Levantamento de espécies fimícolas associadas à mosca. Revista Brasileira de Entomologia 39: 249-258.

Gardner, T. A.; M. I. M. Hernández; J. Barlow \& C. A. Peres. 2008. Understanding the biodiversity consequences of habitat change: the value of secondary and plantation forests for neotropical dung beetles. Journal of Applied Ecology 45: 883-893.

Halffter, G. 1991. Historical and Ecological Factors Determining the Geographical Distribution of Beetles (Coleoptera: Scarabaeidae: Scarabaeinae). Folia Entomológica Mexicana 82: 195-238.

Halffter, G. \& W. D. Edmonds. 1982. The nesting behavior of dung beetles (Scarabaeinae): an ecological and evolutive approach. México, Instituto de Ecología, 177 p.

Halffter, G. \& M. E. Favila. 1993. The Scarabaeinae (Insecta: Coleoptera) an Animal Group for Analyzing, Inventorying and Monitoring Biodiversity in Tropical Rainforest and Modified Landscapes. Biology International 27: 15-21.

Halffter, G.; M. E. Favila \& V. Halffter. 1992. Comparative studies on the structure of scarab guild in tropical rain forest. Folia Entomológica Mexicana 84: 131-156.

Halffter, G. \& E. G. Matthews. 1966. The Natural History of Dung Beetles of the Subfamily Scarabaeinae (Coleoptera: Scarabaeidae). Folia Entomologica Mexicana 12/14: 1-312.
Hanski, I. 1989. Dung beetles, p. 489-511. In: H. Lieth \& M. J. A. Werger (eds.). Tropical Rain Forest Ecosystems. Amsterdam, Elsevier Science Publishers BV, 714 p.

Hanski, I. 1991. Dung insect community, p. 5-21. In: I. Hanski \& Y. Cambefort (eds.). Dung Beetle Ecology. New Jersey, Princeton University Press, $481 \mathrm{p}$.

Hanski, \& Y. Cambefort. 1991. Dung Beetles Ecology. New Jersey, Princeton University Press, 520 p.

Howden, H. F. \& V. G. Nealis. 1975. Effects of clearing in a tropical rain forest on the composition of the coprophagous scarab beetle fauna (Coleoptera). Biotropica 7: 77-83.

Janzen, D. H. 1983. Seasonal changes in abundance of large nocturnal dung beetles (Scarabaeidade) in a Costa Rican deciduous forest and adjacent horse pastures. Oikos 33: 274-283.

Kenney, A. J. \& C. J. Krebs. 2000. Programs for Ecological Methodology. Vancouver, University of British Columbia Press, $620 \mathrm{p}$.

Klein, B. 1989. Effect of forest fragmentation on dung and carrion beetle communities in Central Amazonia. Ecology 70: 1715-1725.

Krebs, C. J. 1999. Ecological Methodology. California, Benjamin Cummings, $620 \mathrm{p}$.

Lobo, J. M. \& F. Martín-Piera. 1999. Between-group differences in the Iberian dung beetle species-area relationship (Coleoptera: Scarabaeidae). Acta Oecologica 20: 587-597.

Lovejoy, T. E.; J. M. Rankin; R. O. Jr. Bierregard; K. Jr. Brown; L. H. Emmons \& M. E. Van Der Vort. 1984. Ecosystem decay of Amazon forest remnants, p. 295-325. In: M. H. Nitecki (ed.). Extinctions. Chicago, University of Chicago, $466 \mathrm{p}$.

Lovejoy, T. E.; R. O. Jr. Bierregard; A. Rylands; G. Malcolm; E. C. Quintela; L. H. Harper; K. Jr. Brown; A. G. Powell; G. V. N. Powell; H. O. Schubart, \& B. Hays. 1986. Edge and other effects of isolation on Amazon fragments, p. 257-285. In: M. E. Soulé (eds.). Conservation biology, the science of scarcity and diversity. Massachesetts, Sinauer Associates, 584 p.

Nealis, V. G. 1977. Habitat association and community analysis of south Texas dung beetles (Coleoptera: Scarabaeidae). Canadian Journal of Zoology 55: 138-147.

Rensburg, B. J. V. \& A. Botes. 2002. The verification and application of bioindicators: a case study of dung beetles in a savanna ecosystem. Journal of Applied Ecology 39: 661-672.

Silva, F. A. B.; M. I. M. Hernández; S. Ide \& R. C. de Moura. 2007. Comunidade de escarabeíneos (Coleoptera: Scarabaeidae) copronecrófagos da região de Caruaru, Pernambuco, Brasil. Revista Brasileira de Entomologia 51: 228-233.

StatSoft, Inc. 2004. STATISTICA (data analysis software system), version 7. <http:www.statsoft.com>. Access 21/07/2008.

Stumpf, I. V. K. 1986. Study of the scarab fauna in Mandirituba, Parana, Brazil. Acta Biológica Paranaense 15: 125-153.

Tabarelli, M. 1998. Dois Irmãos: O Desafio da Conservação Biológica em um Fragmento de Floresta Tropical, p. 311-323. In: I. C. Machado; A. V. Lopes \& K. C. Porto (eds.). Parque Estadual de Dois Irmãos: estudos em um Remanescente de Mata Atlântica em Área Urbana (Recife - Pernambuco - Brasil). Recife, Editora Universitária da Universidade Federal de Permambuco, $326 \mathrm{p}$. 